\title{
Nature Relatedness as a Predictor of Psychological Well-Being: A Study of Indonesian Urban Society
}

\author{
Bartolomeus Yofana Adiwena and Ratna Djuwita \\ Faculty of Psychology \\ Universitas Indonesia
}

\begin{abstract}
The complexity of urban life can have its own negative impact on the psychological well-being (PWB) of its society. It is thought that the natural environment can reduce that negative impact and have an important role in the health and well-being of urban society. Nature relatedness (NR) is a construct which illustrates an approach to, or a subjective individual relationship with, the natural environment. Previous research indicates that NR has a positive relationship with the PWB of a person; however such research used a sample of society in Western countries. Does a relationship between NR and PWB exist also in the context of urban Indonesian society? The principle aim of this research was to prove a relationship between NR and PWB, using a sample from urban Indonesian society. This research was of a non-experimental nature, with 178 respondents. Analysis using structural equation modeling (SEM) proved that the NR level of an individual is a positive predictor of the PWB they have. For this reason, the higher the level of NR an individual has, the higher also is the level of PWB they will have. The authors recommend that all people managing vested interests pay attention not only to situational factors, such as the existence of open green spaces and the cleanliness of the environment, but also pay attention to dispositional factors, such as NR, which is proven to have an important role for PWB.
\end{abstract}

Keywords: nature relatedness, psychological well-being, urban Indonesian society, SEM

Kompleksitas kehidupan urban dapat membawa dampak negatif tersendiri bagi psychological well-being (PWB) masyarakatnya. Lingkungan alami diyakini dapat mengurangi dampak negatif tersebut dan berperan penting bagi kesehatan dan well-being masyarakat urban. Beberapa penelitian terdahulu menunjukkan bahwa level hubungan subyektif individu dengan lingkungan alami terkait dengan PWB. Nature relatedness (NR) merupakan salah satu konstruk yang menggambarkan kedekatan atau hubungan subyektif individu dengan lingkungan alami. Penelitian terdahulu yang dilakukan oleh Nisbet, Zelenski, dan Murphy (2011) menunjukkan bahwa NR berhubungan secara positif dengan PWB individu, namun penelitian tersebut menggunakan sampel masyarakat di negara Barat. Apakah hubungan antara NR dan PWB juga terjadi dalam konteks masyarakat urban di Indonesia? Tujuan utama penelitian ini adalah untuk membuktikan hubungan antara NR dengan PWB menggunakan sampel masyarakat urban di Indonesia. Penelitian ini merupakan penelitian korelasional noneksperimental dengan jumlah responden sebanyak 178 orang. Analisis menggunakan structural equation modeling (SEM) mengonfirmasi hasil penelitian terdahulu, yaitu membuktikan bahwa level NR individu memprediksi secara positif PWB yang dimilikinya. Dengan demikian, semakin tinggi level NR yang dimiliki individu, maka akan semakin tinggi pula PWB yang dimilikinya. Penulis menyarankan seluruh pemangku kepentingan agar tidak hanya memperhatikan faktor situasional seperti keberadaan ruang terbuka hijau dan kebersihan lingkungan, tetapi memperhatikan juga faktor disposisional seperti NR terbukti berperan penting bagi PWB.

Kata kunci: nature relatedness, psychological well-being, masyarakat urban indonesia, SEM

Psychological health, or well-being, is one of the fundamental matters in the life of every person. The patterns of life, marked by busyness and high work-

Correspondence concerning this article should be addressed to Bartolomeus Yofana Adiwena, Faculty of Psychology, Universitas Indonesia. Jalan Margonda Raya, Depok 16424, Indonesia. E-mail: adiwena.tik@gmail.com loads, rapid changes, population density, hubbub, and pollution, together with technological and workplace advances, show a number of the stressors which can threaten the well-being of urban society. In a survey concerning well-being, conducted by Cigna Indonesia, the well-being score for urban residents of Indonesia 
has undergone a decline, from 62.8 in 2017 , to 61.0 in 2018 (Putra, 2018). One on the causes of this is the increasing shortage of recreational time, and time spent with family and friends. Technological and workplace advances, which are actually supposed to support the life of society, apparently have a negative impact (de Vries, Möller, Wieringa, Eigenraam, \& Hamelink, 2017).

The pressure felt by urban society is made worse by the fact that a number of supportive elements for life in urban society are also in poor condition. One example is the existence of open green spaces (OGS), which have functions both ecological and social. In Jakarta, West Java, the amount of OGS is only 9.9 percent of the entirety of the surface area, and in Makassar, South Sulawesi, it is only 13 percent, whereas the OGS Law specifies a minimum of 30 percent of the area of a city be OGS (Rudi, 2016). A large percentage of cities in Indonesia do not fulfill that minimum requirement. There is still a lot of homework needing to be done to increase the quality of life and well-being of urban societies.

Psychological well-being (PWB) may be defined as the degree to which an individual can function optimally in life. This construct was developed by Ryff (1989), referring to a number of concepts of development theories, personal growth and mental health. According to Huppert (2009), a person having good PWB is someone whose life is going well, that is who has good feelings and who functions effectively. Continuing PWB does not mean that the person needs to feel good all of the time. Saddening emotional experiences (for instance, disappointment, failure, sorrow) are part of life, and will not disrupt PWB, as long as those emotions can be managed correctly. PWB will be disturbed when these negative emotions are longlasting, and disrupt the effective functioning of a person, in their daily life.

There is a lot of research indicating that someone with good PWB will obtain benefits in life. As an example, the study by Ryff, Singer, and Love in 2004 shows that PWB has a strong correlation with levels of cortisol (a stress preventative hormone), HDL cholesterol, and quality sleep patterns. Other researches show that a person having good PWB tends to have better (physiological) health (Boehm \& Kubzansky, 2012; Steptoe, Deaton, \& Stone, 2015), to use a more positive and constructive power of attribution (Ryan \& Deci, 2001), and to have more independent capability and plans for their own career (Strauser, Lustig, \& Çiftçi, 2008).

Scientists and writers in a number of scientific fields accept that the natural environment's role in he- alth and well-being is important (Feral, 1998; Gilchrist et al., 2015; Kuo, 2015; Lee et al., 2011; Passmore \& Howell, 2014). Several pieces of research have proven that the presence of the natural environment can raise the cognitive performance of the individual (Berman, Jonides, \& Kaplan, 2009), reduce levels of stress and tension (Cole \& Hall, 2010; Roeet al., 2013), reduce blood pressure and cortisol hormone levels (Lee et al., 2011), and indeed raise the self-esteem and mood of a person (Barton \& Pretty, 2010). Overall, these various pieces of research show that the natural environment is a vital factor, having positive contribution to the development of optimal human feelings and functions.

A large portion of the research into nature and human health (physical and psychological) is centered upon the contact or interaction of an individual with the natural environment surrounding them (Biedenweg, Scott, \& Scott, 2017; Chow \& Lau, 2015; Dopko, Zelenski, \& Nisbet, 2014; Russell et al., 2013). Besides this trend, there is a very interesting field, one which has as yet not received a lot of attention from researchers, that is the subjective relationship between an individual and nature (e.g., Mayer \& Frantz, 2004; Nisbet, Zelenski, $\&$ Murphy, 2011).Research concerning the role of the natural environment in relation to human well-being should not be focused upon only the environmental conditions and time spent by a person in nature (situational factors), but it is also important to examine the role of dispositional factors, such as feelings or the subjective relationship of an individual with the natural environment (Nisbet, Zelenski, \& Murphy, 2011).

Nature relatedness (NR) is one construct to illustrate the level of the subjective relationship between a person and the natural environment, offered by Nisbet, Zelenski, and Murphy (2009). NR illustrates not only the tendency of a person to engage in pro-environmental activities, or to admire the beauty offered by nature, but also their overall understanding and appreciation concerning the connectedness between mankind and all living creatures in nature, as well as of the importance of all aspects of nature, indeed even those which are not attractive, and tend to be frightening, such as cockroaches and snakes. NR covers the affective, cognitive and physical aspects of relations between humans and the natural environment surrounding them, so as to be considered as the most complete construct illustrating all of the important elements in the relationship between mankind and nature (Nisbet, Zelenski, \& Murphy, 2009).

The construct of NR is based upon an evolutionary psychological approach, i.e., the biophilia hypothesis. 
The biophilia hypothesis is a viewpoint convinced that mankind has an intrinsic (innate) need to be connected to, or affiliated with, other living creatures, or with nature (Kellert \& Wilson, 1993). There is a conviction that the relationship with nature gave a lot of adaptive advantages to the ancestors of humanity in times past, which has been handed down until today. Food, drink and places of shelter were afforded mankind by nature. Besides these, omens of the weather, of disaster, and even of the presence of wild predators were obtained from natural signals. Evidence of the biophilia hypothesis can be seen from the popularity of open-air activities, visits to zoological gardens, gardening, and relationships with pet animals (Kellert \& Wilson, 1993). The environment in which mankind now lives is very different from the environment of times gone past. Urbanization, and the development of technology, has not suddenly made the need for affiliation with nature undergo a decline. Mankind still has a need to be close to nature.

The research by Nisbet, Zelenski, and Murphy (2011) showed that NR has a positive correlation to PWB, both with samples of tertiary students, as well as workers and employees, in Canada. Besides this, NR is also the mediator for the boosting of vitality for tertiary students studying subjects concerning nature. In 2014, Martyn and Brymer also conducted research concerned with NR and mental health. The tied variable used in that research was levels of anxiety, and used a sample from the people of Australia. The results of that research indicated that NR had a direct relationship with the decline in the level of anxiety overall, and levels of cognitive anxiety. These results again stressed that NR has a positive impact on mental health.

Several studies have shown that the role of culture and individual attitudes and behavior, related to the environment, cannot simply be ignored. Research by Schultz (2001) related to concerns over the condition of the environment (environmental concern), for instance, shows that there are different types of concern predominant in various countries or cultures. With a sample from societies having an individualistic culture, concern is centered upon the impact of environmental damage on personal health, finances, quality of life and the availability of resources for the individual (egotistic). On the other hand, with a sample from a society with a collectivistic culture, concern is focused upon the impact of environmental damage on humankind and future generations (altruistic). Research by Tam (2013) which tested inter-constructional relationship similarities and differences with nature (including NR) for a sample of people from Hong Kong society also indicated results inconsistent with previous research. When various criterion variables were compared with different types of measurements concerning relationships with nature, it was discovered that the well-being variable (life satisfaction and emotional balance), was the variable which had the weakest correlation with all measurements (including NR), compared to the other criteria variables in the research. These various discoveries raised concerns over the generalization of previous pieces of research, so that conducting research using a sample from urban Indonesian society became important, in order to prove the consistency of the relationship between NR and PWB, in an intercultural context.

NR is a developing construct, which has not received much attention from researchers (Nisbet, Zelenski, \& Murphy, 2011) as yet at the time of this research. It should be noted that a large portion of research concerning levels of subjective relationships with nature and well-being (Mayer et al., 2009; Nisbet, Zelenski, $\&$ Murphy, 2011) has been conducted using Western (e.g., Canadian and Australian) societal samples. As far as is known, there has as yet been no systematic research conducted, to prove the role of NR levels in relation to well-being, using a sample from urban Indonesian society. A piece of research about a sample from Indonesian society was conducted by Prasetyo, Djuwita, and Ariyanto (2018), but this research did not relate NR to well-being. This raises the question of whether relations between NR and PWB also occur in the context of urban Indonesian society.

There are several theoretical foundations which can be used to explain why NR has a positive relationship with PWB. Firstly, the feeling that one is in touch, and being in touch generally, is proven to predict well-being (Ryan \& Deci, 2001). For example, the research by Diener and Seligman (2002) showed that happy people had a quality in common; they had rich and satisfying social lives. Conversely, loneliness and shyness had a negative correlation with happiness. Connectedness is considered to be one of the basic requirements for humans, and is an important precondition for wellbeing (Baumeister \& Leary, 1995). From the ecopsychological and biophilia perspective, feelings of connectedness are surely not restricted to inter-human relationships, but also involve relations between mankind and the non-human natural world around humans. Secondly, persons with high NR tend to demonstrate greater efforts always to be close to, or interact with, nature, so that these people receive more direct benefits from nature. Research shows that NR has a positive relationship with the frequency of outdoor and o- 


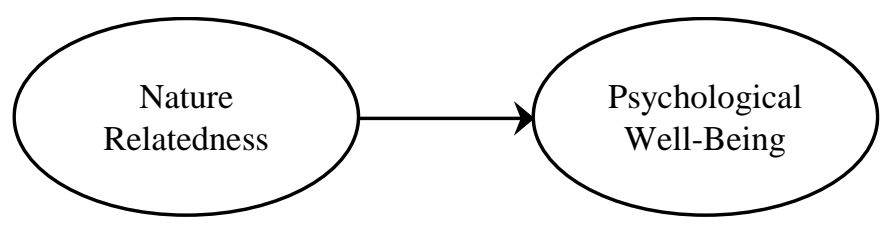

Figure 1. Research hypothesis.

pen-air activities, as well as the ownership of livestock (Nisbet, Zelenski, \& Murphy, 2009). Nature stores active chemical material (active ingredients) which are the antecedents for physiological and psychological health, and which eventually have a positive impact on the general and on-going health of individuals (Kuo, 2015). On the basis of Stress-Reduction Theory (SRT), displays of the natural environment, such as open waters, plants, panoramic scenery and other elements contributing to the continuity of the lives of our ancestors, will produce an automatic response in the form of a decline in physiological fervor, thus eliciting relaxation, as well as a reduction of negative emotions, and an increase in positive feelings (Ulrich et al., 1991). In other words, the individual who relates to, or engages in activities in, natural surroundings, will experience reduction in stress, both physiological and psychological.

This research specifically placed the NR variable as a predictor variable, and the PWB variable as an outcome variable. With the theoretical background previously discussed, the researchers surmised that NR would have a positive relationship with well-being, that is, the higher the level of NR of a person, the higher the experienced PWB. This inference was in accord with the results of previous researchers (Mayer et al., 2009; Nisbet, Zelenski, \& Murphy, 2011), which used samples from Western society. The researchers were convinced that this research could make a theoretical contribution concerning the levels of NR and PWB, which to date had not been studied in Indonesia. The hypothesis model is shown as Figure 1.

\section{Method}

\section{Research Respondents}

This research utilized a non-experimental design, with 178 respondents coming from a number of large cities in Indonesia. There were no particular criteria for the respondents recruited, save that they had to be adults, aged above 18 years. The research sample was selected using the incidental sampling technique, that is, the researchers gave out research questionnaires to whomsoever fulfilled the criteria, and were willing to participate in the research (Sugiyono, 2012). The completion of the questionnaire was conducted offline (94 persons) and online ( 84 persons). The research respondents had the average age of 24.95 years $(S D=8.98)$ and the majority were female $(n=119.67 \%)$. A large proportion of the respondents were high-school and tertiary students $(n=112.63 \%)$. More complete demographic data can be seen in Table 1.

\section{Material}

Psychological well-being. In this research, the PWB variable was measured using the Psychological Well-Being Scale, adapted by the researchers from the original English language scale, constructed by Ryff and Singer (1996). The scale comprises six dimensions: (1) autonomy; (2) environmental mastery; (3) personal growth; (4) positive relation with others; (5) purpose in life; and (6) self-acceptance. The researchers translated the items into Indonesian (Bahasa Indonesia), added several items in line with society in Indonesia, and conducted a readability test (face validity test). Finally, the measurement instrument used in the research comprised 24 statements using the scale of 1 (greatly disagree) through to 6 (most appropriate). Examples of the items of the Psychological Well-Being Scale are: "Tuntutan kehidupan sehari-hari sering membuat saya tertekan." ("The demands of daily life

Table 1

Demographic Data of Participants

\begin{tabular}{ccc}
\hline $\begin{array}{c}\text { Demographic } \\
\text { Variable }\end{array}$ & Category & $N$ \\
\hline Residence & Jabodetabek & 154 \\
& East Java & 11 \\
& Central Java & 3 \\
& Other & 10 \\
\hline Employment & High School/Univ. Student & 112 \\
& Employee & 54 \\
& Not Yet or Unemployed & 11 \\
\hline Final Education & Senior High School & 100 \\
& 3 Year Degree/Bachelor & 66 \\
& Masters/PhD & 11 \\
\hline
\end{tabular}

Note. *Jabodetabek is a large metropolitan cluster, comprising Jakarta, Bogor, Depok, Tangerang, and Bekasi. 
Table 2

Analysis of Items and Scale Reliability

\begin{tabular}{ccccc}
\hline Variable & Factor & Number of Items & Cronbach's $\alpha$ & Factor Loading (CFA) \\
\hline Psychological Well-Being & Autonomy & 2 & .53 & $0.353-0.738$ \\
& Personal Growth & 2 & .53 & $0.440-0.763$ \\
& Positive Relation with Others & 2 & .42 & $0.404-0.665$ \\
\hline Nature Relatedness & NR-Self & 2 & .68 & $0.501-0.792$ \\
& NR-Perspective & 2 & .37 & $0.278-0.892$ \\
& NR-Experience & 2 & .65 & $0.674-0.733$ \\
\hline
\end{tabular}

often make me depressed.") and "Saya yakin mampu mencapai sesuatu yang saya inginkan dengan potensi yang saya miliki." (I am confident of being able to achieve something I desire, with potential I possess.").

Prior to hypothesis testing, the researchers carried out analysis of the items, to ensure the validity of the measurement instruments. The item analysis was begun by calculating the corrected item-total correlation with the criterion $r>.3$ (Nunnally \& Bernstein, 1994). After deleting items which did not meet the criterion, the researchers carried out an analysis of confirmatory factors (Confirmatory Factor Analysis - CFA). The cut-off criterion used to evaluate the suitability (fit) between the CFA models was: $C F I>0.95$, RMSEA $<0.06$, and SRMR < 0.08 (Hu \& Bentler, 1999). The result was that the Psychological Well-Being Scale had a good construct validity, with $\chi^{2}(6)=3.523, p=.741$, $C F I=1.000, R M S E A=1.000$ [90\% CI 0.000, 0.087], $S R M R=0.032, A I C=2983.850)$. On the basis of the results of item analysis, the researchers had to delete three dimensions which did not fulfill the criteria determined, i.e., the dimensions of environmental mastery, purpose in life, and self acceptance. Eventually, item analysis left three dimensions (autonomy, personal growth, and positive relations with others), with six valid items to be used in hypothesis testing. The results of the CFA and the reliability of the Psychological Well-Being Scale, after the deletion of the items, can be seen at Table 2 .

Nature relatedness. The NR variable was measured using the Nature Relatedness Scale adapted by the researchers from the original English scale compiled by Nisbet, Zelenski, and Murphy (2009). The Nature Relatedness Scale comprises three dimensions: (1) the NR-Self reflecting the strength of the self-identification of the individual with the natural environment; (2) the NR-Perspective, reflecting the personal connection of a person with the environment, manifested in his or her attitude and behavior; and (3) the NR-Experience, reflecting physical intimacy with, and interest in nature of the individual. Adaptation of the measurement instrument was begun with the translation of the items into Indonesian (Bahasa Indonesia), and the addition of several items in line with the conditions of society in Indonesia. Afterwards, the readability testing (face validity test) using a small sample was conducted. The results of the readability testing resulted in several revisions of items. Eventually, the measurement instrument used in the research comprised 24 statements using scales 1 (greatly disagree) through to 6 (very appropriate). Examples of the Nature Relatedness Scale are: "Saya menikmati kegiatan luar ruangan, bahkan dalam cuaca yang tidak menyenangkan." ("I enjoy outdoor activities, even in inclement weather.") and "Saya sangat sadar akan masalah lingkungan." (I am very aware of environmental problems.").

Item analysis was conducted on the 24 items of the Nature Relatedness Scale, using corrected item-total correlation (CITC) with the criterion of $r>.3$ (Nunnally $\&$ Bernstein, 1994). After that, the researchers conducted confirmatory factor analysis (CFA) with the cut-off criterion identical to that preceding it. The results of CFA analysis indicated that Nature Relatedness Scale had a sound construct validity, with $\chi^{2}(6)$ $=8.455, p=.207(>.05), C F I=0.985, R M S E A=0.049$ [90\% CI 0.000, 0.119], SRMR =0.030, AIC $=2850.758$ ). Item analysis left six items, valid for use in data analysis. The results of the CFA and the reliability of the Nature Relatedness Scale, after item deletion, can be seen in Table 2.

\section{Procedure and Method of Analysis}

The extraction of data was conducted using a questionnaire in online and offline ways to obtain the accumulation of data which was heterogeneous and covered a variety of regions and social groups. The sounds, number and order of items used in the two methods of data extraction were identical. The researchers told the respondents that the research was aimed at examining the patterns of interaction of individuals with the natural and social environment around them. The researchers gave remuneration to the respondents in the form of the opportunity to take part in a "GoPay" (an Indonesian payment service like 'BPay' or 
Table 3

Means, Standard Deviations, and Intercorrelations Amongst Dimensions and Variables

\begin{tabular}{lcccccccc}
\hline Variable & 1 & 2 & 3 & 4 & 5 & 6 & 7 & 8 \\
\hline 1. NR-Self & 1 & & & & & & & \\
2. NR-Perspective & $.36^{* *}$ & 1 & & & & & & \\
3. NR-Experience & $.54^{* *}$ & $.22^{* *}$ & 1 & & & & \\
4. NR (Total) & $.82^{* *}$ & $.65^{* *}$ & $.82^{* *}$ & 1 & & & \\
5. Autonomy & $.28^{* *}$ & .14 & .14 & $.24^{* *}$ & 1 & & \\
6. Personal Growth & $.34^{* *}$ & .12 & $.32^{* *}$ & $.35^{* *}$ & $.34^{* *}$ & 1 & & \\
7. Positive Relation & $.34^{* *}$ & $.22^{* *}$ & $.30^{* *}$ & $.37^{* *}$ & .14 & $.31^{* *}$ & 1 & \\
8. PWB (Total) & $.45^{* *}$ & $.23^{* *}$ & $.35^{* *}$ & $.45^{* *}$ & $.69^{* *}$ & $.75^{* *}$ & $.70^{* *}$ & 1 \\
$M$ & 9.67 & 9.92 & 8.78 & 28.38 & 8.66 & 9.67 & 8.74 & 27.07 \\
SD & 1.59 & 1.59 & 2.08 & 4.04 & 1.72 & 1.57 & 1.79 & 3.61 \\
\hline Notes. & ${ }^{* *}$ Correlation is significant at $p<.01 ; *$ Correlation is significant at $p<.05$. & & & &
\end{tabular}

'PayPal') raffle, to the value of IDR 375,000 each for the 25 lucky respondents. All data was collected over the period of one month. The researchers used Structural Equation Modeling (SEM) analysis, utilizing the Lavaan packet, version 0.6-3 (Rosseel, 2012) in R software version 3.5.1, to explore the connections between NR and PWB. The research has received the approval of the Dewan Kaji Etik Fakultas Psikologi Universitas Indonesia (Ethical Studies Board of the Faculty of Psychology of Universitas Indonesia).

\section{Results}

Descriptive analysis of the results of the research showed that the average NR score reported by the respondents was $4.74(S D=0.66)$, whilst the average PWB score reported was $4.44(S D=0.56)$. In this descriptive analysis, the researchers used absolute criteria as a reference to determine the category of the respondent input, i.e., the ideal or maximum measurement achievable by the respondents (Cohen, Swerdlik, \& Sturman, 2013). With a six-scaled statement, the average maximum score achievable is 6 , with a median of 3.5. Thus, the average NR and PWB score of the respondents in this research can be categorized as moderate, tending towards high.

The results of the t-test indicates that there is no statistical difference in NR scores from female and male respondents, with $t(176)=0.03, p=$ n.s. For the employment variable, the researchers grouped those into two principle categories, i.e., high school and university students $(n=112)$ and other than high school and university students $(n=65)$. The researchers did not discover any significant statistical difference in the NR score between high school and university students compared to other than high school and university students $(t(175)=-1.77, p=$ n.s. $)$ Thus, it may be concluded that the demographic variables for respondents (gender and employment) in this research did not produce significant score variations.

The following analysis is a study of the inter-variable correlations studied. As the researchers surmised, this study states there is a significant positive correlation between NR and PWB (see Table 3). Analysis of each formative dimension variable of NR and PWB indicates that a large portion of the formative dimensions of NR have a positive correlation with the formative dimensions of PWB. The positive relation dimension is the PWB dimension having the largest correlation with the total score for NR $(r=.37 ; p<.01)$, whilst NR-Self dimension is the NR dimension which has the biggest correlation with the total PWB score $(r=.45 ; p<.01)$. When it was analyzed using the total score, the NR variable also still had a significant correlation with PWB $(r=.45 ; p<.01)$.

Analysis using Structural Equation Modeling (SEM) was preceded by seeing whether the research model put forward fulfilled the fit criterion or not. Bagozzi and Yi (1988) suggested that there were three indices which needed to be used to examine the suitability of a research model (goodness of fit): (1) the criteria of initial suitability (preliminary fit criteria); (2) overall model suitability (overall model fit); and (3) suitability of the internal structure of the model (fit of the internal structure of the model). This research used the three named indices to examine the suitability of the models advanced in the research.

The models advanced in the research fulfill the criteria of initial suitability (preliminary fit criteria), because there was no data anomaly found in the form of a variance error with a negative value and correlation coefficient having a value of more than 1 (one). The overall suitability of the model (overall model fit) was tested via the evaluation of the compatibility (fit) between the hypothesized model and the actual data, $\mathrm{u}$ - 


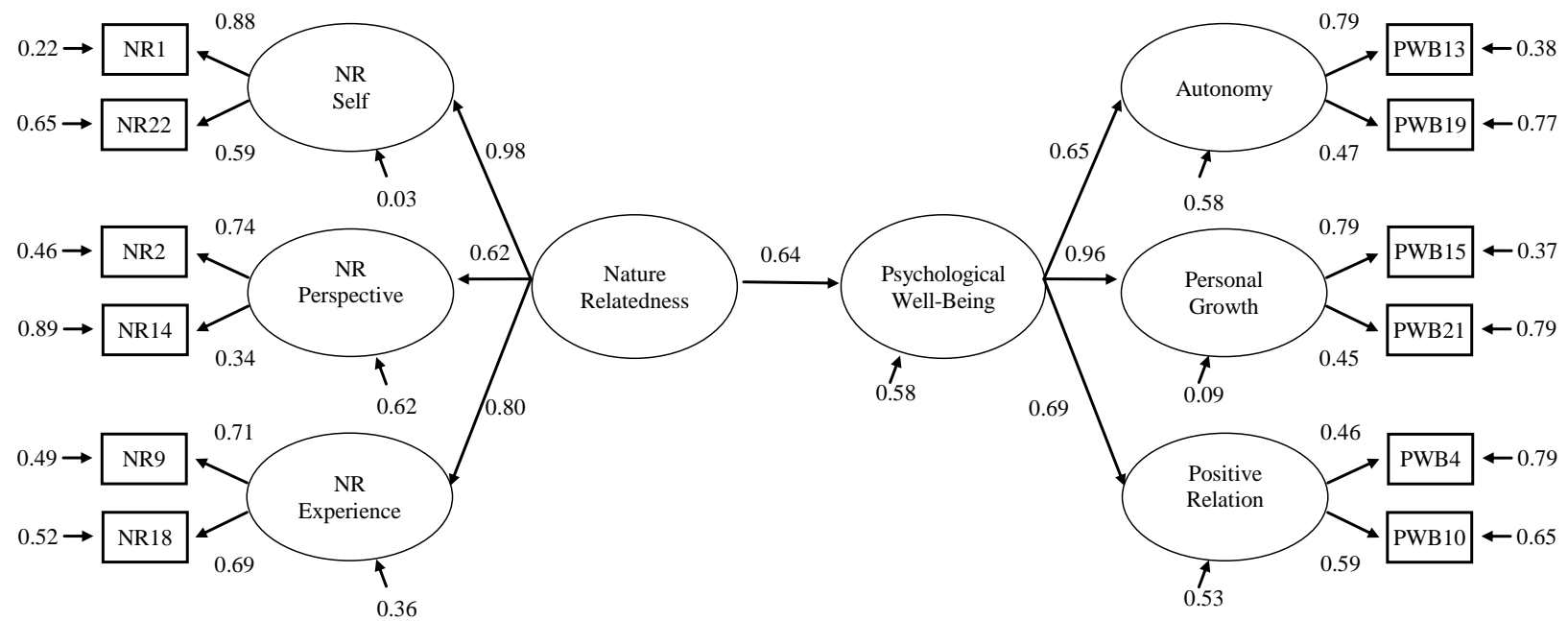

Figure 2. SEM model of NR and PWB relationships.

sing the criteria: $C F I>0.95, R M S E A<0.06$, and $S R M R$ $<0.08$ (Hu \& Bentler, 1999). The $\chi^{2}$ (chi-squared) coefficient was also reported, however it was not used as a principle criterion, because this value tended to reject the model, based upon the large size of the sample (Bentler \& Bonett, 1980).The results indicated that the hypothesized research model was acceptable, or fit the [results] $\chi^{2}(43)=57.909, p=.064(<.05), C F I$ $=0.95, R M S E A=0.051$ [90\% CI 0.000, 0.082], SRMR $=0.060$, AIC $=5802.274)$. Bagozzi and Yi (1988) also stated that the internal structure of the model is said to be sound, if the item reliability, the composite variable reliability and the average variance extracted is greater than .50 . The findings of this research show that the degree of the composite variable reliability ranges from .366 to .683 , and the average variance extracted ranged from .236 to .594 . These showed that the model of the research shows quite sound internal structure suitability. The SEM Model is shown in Figure 2.

This analysis was intended to test whether the level of relationship to nature (NR) could significantly predict the psychological well-being (PWB) of an individual. The model put forward by the researchers used latent variables of the second order. The load of factors for each measurement model indicates a sound and significant result. Analysis of the structural model shows that the NR of a person significantly predicts the PWB which they have $(\beta=0.64, p<.01)$. The residual variance of the PWB was .58 , indicating that NR explains around $41.5 \%\left(R^{2}=.415\right)$ or the variance in PWB. Statistical power analysis, using G*Power with an effect size of $\left(f^{2}\right)=0.15, \alpha=.05$, and a sample size of $n=178$ people, resulted in a power of .99 . The findings of this research simultaneously replica- ted previous findings concerning the relationship between NR and well-being, using a sample of matureage people, in the context of urban Indonesian life.

\section{Discussions}

The aim of this research was to examine the level of the subjective relationship with nature (NR), of an individual, in relation to their well-being (PWB). The results of this research support the hypothesis put forward, that the level of NR of a person has a positive correlation with their PWB $\left(\beta=0.64, p<.01, R^{2}=.415\right)$. Thus, the higher the level of NR which a person has, the higher too is the level of their well-being (PWB). The relationship between NR and PWB was also confirmed through the analysis of every compositional dimension of the two variables (Table 3). A large portion of the confirmatory dimensions of NR were significantly correlated with the confirmatory dimensions of PWB. This finding once more proved and confirmed the important role of the natural environment for human life.

The results of this research strengthen the results of the research by Nisbet, Zelenski, and Murphy (2011), by proving that there is a strong and significant direct effect between NR and PWB. This relationship was proven, using a sample from Indonesian urban society. The research could indicate that difference in the pattern of the relationship between NR and well-being indicated in the research by Tam (2013) was possibly not caused by cultural differences between the West and the East, but by other specific factors in that research. Although this research was not designed to 
conduct any inter-cultural comparison, the results can give surety that the relationship between NR and PWB occurs also in the societal context an Eastern culture, particularly in Indonesia.

There were found two mechanisms which possibly may explain why the levels of NR can predict PWB. The first mechanism uses the stress reduction theory (SRT), which focuses on the role of contact with, or display of, nature. Someone having a high level of NR possibly may absorb greater advantage, or physical and psychological benefit from nature than someone having low levels of NR (Capaldi, Dopko, \& Zelenski, 2014). This can occur because a high level of NR can support an individual engaging in an increasing amount of activity in nature, or interacting with other living creatures and the natural environment, and the natural environment has been proven to have large amounts of both physical and psychological benefits for humankind (Feral, 1998; Gilchrist et al., 2015; Kuo, 2015; Lee et al., 2011).Several pieces of research also show that NR is positively related to contact with, and activities in, nature (e.g., caring for stock; Mayer \& Frantz, 2004; Nisbet, Zelenski, \& Murphy, 2009). Ongoing interaction with nature by a person will possibly slowly increase their PWB.

The relationship between NR and PWB can also be explained using the self-determination theory (Ryan $\&$ Deci, 2001). On the basis of the self-determination theory, fulfillment of basic human needs, such as connectedness (relatedness), can deliver satisfaction and happiness in life. Connectedness is one of the basic human needs, and is an important precondition for wellbeing. From a biophiliac perspective, activities in, or interaction with, the natural environment can fulfill the needs of mankind for connections with other living creatures (Kellert \& Wilson, 1993). With those needs fulfilled, an individual will feel safe and comfortable to explore the world, and develop his or her own potential. In other words, the more an individual feels connected to the natural environment, the more they will be able to optimize his or her own potential.

This research shows that NR is related to the three formative dimensions of PWB, these being independence (autonomy), personal development (personal growth), and positive relationships (positive relations). The heavy burdens and high demands of employment, rapid changes, dependence upon technology, and consumerism, can be serious threats for feelings of independence in urban society, which is one of the important aspects of PWB. Life for urban society is very vulnerable to influence from demands external to personal values. (Ridder, 2005).In these conditions, the natural environment can become the antidote, which can bring back this feeling of independence. Being in, and engaging in activities in, the natural environment can protect an individual from unwanted external social influences or demands, and also increase their ability to focus on an authentic version of themselves (Ridder, 2005). The natural environment can be a facility to "run away" from urban society, to rediscover the feeling of independence, discover again just what a person wants, without being dictated to by external demands around them.

Personal growth is a process of self-comprehension and development, which continues on to the achievement of the full potential of a person (Ryff, 1989). The circumstances and mental ability (mind) of mankind is an essential part of this process of personal growth. Once again, the natural environment plays an important role in increasing human mental ability or performance. Empiric research conducted by Atchley, Strayer, and Atchley (2012) indicated that the activities of a person in the natural environment can raise the creative reasoning, problem-solving ability, critical thinking and personal introspection of the individual. In other words, there is a possibility that high levels of NR can facilitate a person increasing their understanding, and desire always to engage in self-development, in accordance with the ability they possesses.

Similarly to the discoveries made in the research by Nisbet, Zelenski, and Murphy (2011), this research discovered that the positive relations dimension of PWB had the greatest correlation with NR. It was found that there was a possibility that high levels of NR also facilitated the formation of positive social relationships. Individuals having high levels of NR had awareness and appreciation of the natural environment surrounding them, the plants, animals and their fellow humans. This relationship may be involved in the functional emotional role of a person. Various pieces of research have indicated that high levels of NR can raise positive emotions and the satisfaction with life of a person, as well as reduce negative emotions and symptoms of depression, or anxiety (Martyn \& Brymer, 2014; Nisbet, Zelenski, \& Murphy, 2011; Tam, 2013). With more positive emotions, a person becomes more open, and able to develop positive relationships with others. If this assumption is correct, NR can be said to be one personality aspect (trait) which is particularly vital for urban society, because it facilitates an individual becoming closer, not only to the natural environment, but also to the social environment around them; precisely the antidote needed against the problems of the city, which is very individualistic and environmentally un- 
friendly.

This research also showed that the role of the natural environment is not limited to that of emotional recovery (recuperative effect), but is even more crucial as one of the resources of human well-being. A change of perspective is required from all sides, in the viewing of the natural environment. The natural environment should be seen not only as a "recuperative medicine", utilized when mankind suffers negative situations, but also must be seen as an important element supporting the on-going quality and soundness of human life, needing always to be guarded and conserved. Society, particularly the children, needs to be accustomed to engaging in open-air activities as often as possible, not only when affected by boredom and requiring refreshment. The more frequently a person engages in open-air activities, the higher their levels of NR will be (Nisbet, Zelenski, \& Murphy, 2011), and these will eventually influence their overall PWB.

Besides providing many findings proving that the natural environment (situational and dispositional factors) had a very good effect on well-being, the research also indicated that people tend to make mistakes in predicting and discounting the benefits of the natural environment for their well-being (Nisbet and Zelenski, 2011). This phenomenon, together with the tendency towards engaging in indoor activities, and recalling the urbanization and size of the population, can cause the loss of opportunities to obtain positive benefits from the natural environment. The effects of this are not only a decline in the well being of the planet. It is a big task for all mankind to raise societal awareness of the important role of the natural environment, not only for the physiological health, but also for the psychological health, of all mankind.

The question of what is the best method for raising the level of closeness to nature is one to which the response is very complex. After succeeding in proving the relationship between NR and PWB in the context of Indonesian urban society, a subsequent interesting challenge would be to identify a number of factors causing, or influencing, the level of the closeness of an individual to nature, and to see what is the effectiveness of these several factors. As an example, research by Nisbet, Zelenski, and Murphy (2011) indicated that the delivery of environmental education can raise the levels of NR of a person. Families and parents can also have vital roles in introducing and cultivating pro-environmental norms in children early (Matthies, Selge, \& Klöckner, 2012). Experimental or longitudinal research concerning the creation of closeness to nature can make a great theoretical and practical contribution.
By knowing the factors which form or influence the level of the closeness of an individual to nature, it is possible to formulate a precise and on-going programme or intervention, from childhood, so that the benefits of the natural environment can really be felt by society' members, in an Indonesian urban environment.

Looking at this relationship between NR and PWB, it is logical for people to assume and anticipate a negative effect, which would be counter-productive to well-being. As previously discussed, the subjective level of relationships with nature consistently predicts a sound attitude and concern for the environment (Mayer \& Frantz, 2004; Nisbet, Zelenski, \& Murphy, 2009). There is the possibility that an individual who considers nature to be part of themselves (sense of self) can view the damage occurring to nature as being damage actually happening to themselves (Capaldi, Dopko, \& Zelenski, 2014). In line with the increase in knowledge, awareness and empirical evidence concerning climate change, or environmental damage, a person having a high level of NR can actually undergo a decline in happiness, rather than an increase. One of the future challenges faced is the exploration of factors which moderate the relationships between NR and PWB so that it may be possible to determine that the level of NR of an individual has a positive effect, and is not counter-productive to well-being.

\section{Limitations}

Firstly, the research uses a reasonably small sample which may have been the cause of many items and dimensions of the measurement instruments having to be deleted, to obtain a model fit. According to Jackson (2003), the ideal sample size is 20 persons for one parameter. With 12 observed variables, the research ideally required 240 respondents. Secondly, this research sample had relatively homogenous characteristics, that were dominated by high school and tertiary students living in the megapolis compromising the cities of Jakarta, Bogor, Depok, Tangerang, and Bekasi (Jabodetabek), in Western Java. Although the researchers did not find that these characteristics did not cause any significant differences in NR scores, the results from this relatively homogenous sample cannot convincingly be generalized to apply to the population of Indonesian urban society in general. Thirdly, the research measured only the PWB variable as an outcome variable representing well-being in general. The construct of well-being is a complex one. There are opinions that well-being should be viewed from a hedonic viewpoint, and other opinions that it should be viewed from a eu- 
daimonic viewpoint (Dodge, Daly, Huyton, \& Sanders, 2012). The use of a variety of measurements of happiness and well-being could have enriched this study.

\section{Conclusion and Research Recommendations}

Urban life, filled with challenges, can threaten the well-being of urban society. The results of this research suggest a sound solution for the well-being of urban society, which is by elevating the trait of nature relatedness (NR) in that society. Without denying natural situational factors, such as the existence of green open spaces and the cleanliness of the environment, one might also focus on the dispositional factors possessed by every individual, to increase well-being. This research proves that a person who has emotional, cognitive and physical closeness to the natural environment surrounding them will have a positive level of independence, personal development and social relations. Development of open green spaces and other efforts at nature conservation need to be accompanied by a strategy to ensure that individuals are aware of, know, and not infrequently conduct activities in, nature. Every person, particularly those still children, needs to know and love the natural environment surrounding them. When urban society has an emotional, cognitive and physical closeness to the natural environment, one may be sure that the well-being and quality of life of urban society can improve.

Further research, it is hoped, will use a research sample with characteristics which are more heterogeneous and representative, such as a sample comprising tertiary students and workers, will collect data from more cities in Indonesia, and will conduct measurement of happiness or well-being using a number of perspectives or constructs, so as to be more comprehensive. NR is a developing variable, and has not received a great deal of attention from researchers as of the time of this research, so that there are still many theoretical gaps requiring answers. Further research needs to uncover the mechanisms behind the relationships between NR and well-being, by proving mediating or moderating factors for the relationship between the two, so that these relationships may be more soundly explained.

\section{References}

Atchley, R. A., Strayer, D. L., \& Atchley, P. (2012). Creativity in the wild: Improving creative reasoning through immersion in natural settings. PLoS ONE, 7(12), e51474; 1-3. https://doi.org/10.1371/journal. pone.0051474

Bagozzi, R. P., \& Yi, Y. (1988). On the evaluation of structural equation models. Journal of the Academy of Marketing Science, 16(1), 74-94.

Barton, J., \& Pretty, J. N. (2010). What is the best dose of nature and green exercise for improving mental health? A multi-study analysis. Environmental Science and Technology, 44(10), 3947-3955. https:// doi.org/10.1021/es903183r

Baumeister, R. F., \& Leary, M. R. (1995). The need to belong: Desire for interpersonal attachments as a fundamental human motivation. Psychological Bulletin, 117(3), 497-529. https://doi.org/10.1037/00332909.117.3.497

Bentler, P. M., \& Bonett, D. G. (1980). Significance tests and goodness-of-fit in the analysis of covariance structures. Psychological Bulletin, 88(3), 588606. https://doi.org/10.1037/0033-2909.88.3.588

Berman, M. G., Jonides, J., \& Kaplan, S. (2009). The cognitive benefits of interacting with nature. Psychological Science, 19(12), 1207-1212. https://doi. org/10.1111/j.1467-9280.2008.02225.x

Biedenweg, K., Scott, R. P., \& Scott, T. A. (2017). How does engaging with nature relate to life satisfaction? Demonstrating the link between environment-specific social experiences and life satisfaction. Journal of Environmental Psychology, 50, 112-124. https:// doi.org/10.1016/j.jenvp.2017.02.002

Boehm, J. K., \& Kubzansky, L. D. (2012). The heart's content: The association between positive psychological well-being and cardiovascular health. Psychological Bulletin, 138(4), 655-691. https://doi.org/ 10.1037/a0027448

Capaldi, C. A., Dopko, R. L., \& Zelenski, J. M. (2014). The relationship between nature connectedness and happiness: A meta-analysis. Frontiers in Psychology, 5, 976; 1-15. https://doi.org/10.3389/fpsyg.2014.00976

Chow, J. T., \& Lau, S. (2015). Nature gives us strength: Exposure to nature counteracts ego-depletion. The Journal of Social Psychology, 155(1), 70-85. https:// doi.org/10.1080/00224545.2014.972310

Cohen, R. J., Swerdlik, M. E., \& Sturman, E. D. (2013). Psychological testing and assessment: An introduction to tests and measurement (8th ed.). New York: McGraw-Hill.

Cole, D. N., \& Hall, T. E. (2010). Experiencing the restorative components of wilderness environments: Does congestion interfere and does length of exposure matter? Environment and Behavior, 42(6), 806823. https://doi.org/10.1177/0013916509347248 de Vries, D. A., Möller, A. M., Wieringa, M. S., Eigenraam, A. W., \& Hamelink, K. (2017). Social comparison 
as the thief of joy: Emotional consequences of viewing strangers' Instagram posts. Media Psychology, 21(2), 222-245. https://doi.org/10.1080/15213269. 2016.1267647

Dodge, R., Daly, A. P., Huyton, J., \& Sanders, L. D. (2012). The challenge of defining wellbeing. International Journal of Wellbeing, 2(3), 222-235. https:// doi.org/10.5502/ijw.v2i3.4

Dopko, R. L., Zelenski, J. M., \& Nisbet, E. K. (2014). Nature salience increases judgments of environmental satisfaction. Ecopsychology, 6(4), 207-217. https:// doi.org/10.1089/eco.2014.0042

Diener, E., \& Seligman, M. E. P. (2002). Very happy people. Psychological Science, 13(1), 81-84. https:// doi.org/10.1111/1467-9280.00415

Feral, C-H. (1998). The connectedness model and optimal development: Is ecopsychology the answer to emotional well-being? The Humanistic Psychologist, 26, 243-274. https://doi.org/10.1080/08873267. 1998.9976975

Gilchrist, K., Brown, C., \& Montarzino, A. (2015). Workplace settings and wellbeing: Greenspace use and views contribute to employee wellbeing at periurban business sites. Landscape and Urban Planning, 138, 32-40. https://doi.org/10.1016/j.landurbplan. 2015.02.004

Hu, L., \& Bentler, P. M. (1999). Cutoff criteria for fit indexes in covariance structure analysis: Conventional criteria versus new alternatives. Structural Equation Modeling: A Multidisciplinary Journal, 6(1), 1-55. https://doi.org/10.1080/10705519909540118

Huppert, F. A. (2009). Psychological well-being: Evidence regarding its causes and consequences. Applied Psychology: Health and Well-Being, 1(2), 137164. https://doi.org/10.1111/j.1758-0854.2009.01008.x

Jackson, D. L. (2003). Revisiting sample size and number of parameter estimates: Some support for the $\mathrm{N}$ :q hypothesis. Structural Equation Modeling: A Multidisciplinary Journal, 10(1), 128-141. https:// doi.org/10.1207/S15328007SEM1001_6

Kellert, S. R., \& Wilson, E. O. (1993). The biophilia hypothesis. Washington: Island Press. https://doi.org/ 10.1177/027046769501500125

Kuo, M. (2015). How might contact with nature promote human health? Promising mechanisms and a possible central pathway. Frontiers in Psychology, 6, 1093. https://doi.org/10.3389/fpsyg.2015.01093

Lee, J., Park, B-J., Tsunetsugu, Y., Ohira, T., Kagawa, T., \& Miyazaki, Y. (2011). Effect of forest bathing on physiological and psychological responses in young Japanese male subjects. Public Health, 125(2), 93-100. https://doi.org/10.1016/j.puhe.2010.09.005
Martyn, P., \& Brymer, E. (2014). The relationship between nature relatedness and anxiety. Journal of $\mathrm{He}$ alth Psychology, 21(7), 1436-1445. https://doi.org/ $10.1177 / 1359105314555169$

Matthies, E., Selge, S., \& Klöckner, C. A. (2012). The role of parental behaviour for the development of behaviour specific environmental norms - The example of recycling and re-use behaviour. Journal of Environmental Psychology, 32(3), 277-284. https://doi. org/10.1016/j.jenvp.2012.04.003

Mayer, F. S., \& Frantz, C. M. (2004). The connectedness to nature scale: A measure of individuals' feeling in community with nature. Journal of Environmental Psychology, 24, 503-515. https://doi.org/10. 1016/j.jenvp.2004.10.001

Mayer, F. S., Frantz, C. M., Bruehlman-Senecal, E., \& Dolliver, K. (2009). Why is nature beneficial? The role of connectedness to nature. Environment and Behavior, 41(5), 607-643. https://doi.org/10.1177/ 0013916508319745

Nisbet, E. K., \& Zelenski, J. M. (2011). Underestimating nearby nature: Affective forecasting errors obscure the happy path to sustainability. Psychological Science, 22(9), 1101-1106. https://doi.org/10. 1177/0956797611418527

Nisbet, E. K., Zelenski, J. M., \& Murphy, S. A. (2009). The nature relatedness scale: Linking individuals' connection with nature to environmental concern and behavior. Environment and Behavior, 41(5), 715740. https://doi.org/10.1177/0013916508318748

Nisbet, E. K., Zelenski, J. M., \& Murphy, S. A. (2011). Happiness is in our nature: Exploring nature relatedness as a contributor to subjective well-being. Journal of Happiness Studies, 12(2), 303-322. https:// doi.org/10.1007/s10902-010-9197-7

Nunnally, J. C., \& Bernstein, I. H. (1994). Psychometric theory (3rd ed.). New York: McGraw-Hill.

Passmore, H-A., \& Howell, A. J. (2014). Nature involvement increases hedonic and eudaimonic wellbeing: A two-week experimental study. Ecopsychology, 6(3), 148-154. https://doi.org/10.1089/eco.20 14.0023

Prasetyo, D. T., Djuwita, R., \& Ariyanto, A. (2018). Who is more related to the nature? A study from Indonesia. E3S Web of Conferences International Conference Series on Life Cycle Assessment: Life Cycle Assessment as A Metric to Achieve Sustainable Development Goals (ICSoLCA 2018), 74, 16. https://doi.org/10.1051/e3sconf/20187408009

Putra, W. D. (2018, July 10). Celaka! Ternyata kita betul-betul kurang piknik. Era Indonesia. Retrieved March 9, 2019 from https://www.era.id/read/nqUw 
0W-celaka-ternyata-kita-betul-betul-kurang-piknik

Ridder, B. (2005). Reorienting environmentalism to nature-inspired-autonomy. Griffith Journal of the Environment, 1, 1-26.

Roe, J. J., Thompson, C. W., Aspinall, P. A., Brewer, M. J., Duff, E. I., Miller, D., Clow, A. (2013). Green space and stress: Evidence from cortisol measures in deprived urban communities. International Journal of Environmental Research and Public Health, 10(9), 4086-4103. https://doi.org/10.3390/ijerph1 0094086

Rosseel, Y. (2012). lavaan: An R package for structural equation modeling. Journal of Statistical Software, 48(2), 1-36. https://doi.org/10.18637/jss.v0 48.i02

Rudi, A. (2016, February 17). Belum ideal, RTH di Jakarta hanya 9,9 persen (F. Ali, Ed.). Kompas. Retrieved April 26, 2018 from https://megapolitan.kom pas.com/read/2016/02/17/19020071/Belum.Ideal. RTH.di.Jakarta.Hanya.9.9.Persen

Russell, R., Guerry, A. D., Balvanera, P., Gould, R. K., Basurto, X., Chan, K. M. A., Klain, S., Levine, J., \& Tam, J. (2013). Humans and nature: How knowing and experiencing nature affect well-being. Annual Review of Environment and Resources, 38, 473-502. https:// doi.org/10.1146/annurev-environ-012312-110838

Ryan, R. M., \& Deci, E. L. (2001). On happiness and human potentials: A review of research on hedonic and eudaimonic well-being. Annual Review of Psychology, 52, 141-166. https://doi.org/10.1146/annu rev.psych.52.1.141

Ryff, C. D. (1989). Beyond Ponce de Leon and life satisfaction: New directions in quest of successful ageing. International Journal of Behavioral Development, 12(1), 35-55. https://doi.org/10.1177/01650
2548901200102

Ryff, C. D., \& Singer, B. (1996). Psychological wellbeing: Meaning, measurement, and implications for psychotherapy Research. Psychotherapy and Psychosomatics, 65(1), 14-23. https://doi.org/10.1159/ 000289026

Ryff, C. D., Singer, B. H., \& Love, G. D. (2004). Positive health: Connecting well-being with biology. Philosophical Transactions of Royal Society B: Biological Sciences, 359(1449), 1383-1394. https://doi. org/10.1098/rstb.2004.1521

Schultz, P. W. (2001). The structure of environmental concern: Concern for self, other people, and the biosphere. Journal of Environmental Psychology, 21(4), 327-339. https://doi.org/10.1006/jevp.2001.0227

Steptoe, A., Deaton, A., \& Stone, A. A. (2015). Psychological wellbeing, health and ageing. Lancet, 385 (9968), 640-648. https://doi.org/10.1016/S0140-6 736(13)61489-0

Strauser, D. R., Lustig, D. C., \& Çiftçi, A. (2008). Psychological well-being: Its relation to work personality, vocational identity, and career thoughts. The Journal of Psychology, 142(1), 21-35. https://doi. org/10.3200/JRLP.142.1.21-36.

Sugiyono. (2012). Memahami penelitian kualitatif. Bandung: Alfabeta.

Tam, K-P. (2013). Concepts and measures related to connection to nature: Similarities and differences. Journal of Environmental Psychology, 34, 64-78. https://doi.org/10.1016/j.jenvp.2013.01.004

Ulrich, R. S., Simons, R. F., Losito, B. D., Fiorito, E., Miles, M. A., \& Zelson, M. (1991). Stress recovery during exposure to natural and urban environment. Journal of Environmental Psychology, 11(3), 201230. https://doi.org/10.1016/S0272-4944(05)80184-7 


\section{Appendix}

\section{Valid Items of Measurement Instruments}

\begin{tabular}{lcl}
\hline \multicolumn{1}{c}{ Dimension } & Code & \multicolumn{1}{c}{ Statement } \\
\hline Autonomy & PWB13 & $\begin{array}{l}\text { I am convinced of my opinions, although sometimes they are at variance with } \\
\text { public opinion. }\end{array}$ \\
\hline PWB19 & $\begin{array}{l}\text { I always evaluate myself on the basis of my own personal standards, not the } \\
\text { standards of others. }\end{array}$ \\
\hline PWB15 & $\begin{array}{l}\text { I am convinced I will be able to achieve whatever I desire, with the potential I } \\
\text { have. }\end{array}$ \\
\hline PWB21 & I feel my life has developed greatly over time. \\
\hline PR-Self & PWB4 & $\begin{array}{l}\text { Up 'till now, I have felt difficulties in maintaining close relationships with } \\
\text { others. } \\
\text { A number of people consider me to be a generous person, ready to make time } \\
\text { free for others. }\end{array}$ \\
\hline NR-Perspective & NR1 & $\begin{array}{l}\text { My relationship with the natural environment is an important part of my life. } \\
\text { I see myself as part of the natural environment. }\end{array}$ \\
\hline NR2 & $\begin{array}{l}\text { According to me, mankind must do something to save the earth from a wide } \\
\text { range of damage. } \\
\text { According to me, whatever I do will not change the situation, nor the problems } \\
\text { regarding the environment, which are occurring in various places on Earth. }\end{array}$ \\
\hline NR-Experience & NR9 & $\begin{array}{l}\text { I will be aware of the existence of green nature, wherever I am. } \\
\text { I am content when doing gardening activities. }\end{array}$ \\
\hline NR18
\end{tabular}

